www.jmscr.igmpublication.org

Impact Factor (SJIF): 6.379

Index Copernicus Value: 71.58

ISSN (e)-2347-176x ISSN (p) 2455-0450

crossref DOI:_https://dx.doi.org/10.18535/jmscr/v6i4.91

Journal Of Medical Science And Clinical Research

IGM Publication

An Official Publication of IGM Publication

\title{
Role of Ondansetron with Dexamethasone and Palonosetron with Dexamethasone as Antiemetic in Laproscopic Surgery under General Anaesthesia: A Comparative Study
}

\author{
Authors \\ Gautam Prajapat ${ }^{1}$, Anita Pareek $^{2}$, Sangeeta Sethia $^{3}$, Kanta Bhati ${ }^{4}$, Sangeeta Meena $^{5}$ \\ ${ }^{1}$ Resident, ${ }^{2}$ Professor, ${ }^{3}$ Medical officer, ${ }^{4}$ Professor, ${ }^{5}$ Senior Resident \\ Department of Anaesthesia, Sardar Patel Medical College \& AGH, Bikaner, Rajasthan \\ Correspondence Author \\ Anita Pareek \\ 4-E-183, JNV Colony, Bikaner, Rajasthan \\ Email: dranitapareek23@gmail.com
}

\begin{abstract}
Background and Aim: Postoperative nausea and vomiting (PONV) is commonly seen after laparoscopic surgery. In this randomized double blind prospective clinical study, we investigated and compared the efficacy of palonosetron with dexamethasone and ondensetron with dexamethasone to prevent postoperative nausea and vomiting after laparoscopic cholecystectomy.

Materials and Method: Sixty patients (18-60 yrs of age) undergoing elective laparoscopic cholecystectomy were randomly allocated one of the two groups containing 30 patients each. Group 1 received ondensetron 4 $\mathrm{mg}$ and dexamethasone $8 \mathrm{mg}$ intravenously as a bolus before induction of anaesthesia. Group 2 received palonosetron $0.075 \mathrm{mg}$ and dexamethasone $8 \mathrm{mg}$ intravenously as a bolus before induction.

Result: The incidence of a complete response (no PONV, no rescue medication) during post operative period is $86.6 \%, 86.6 \%, 93.4 \%$ and $93.4 \%$ in palonosetron group in 0-4,4-12,12-24 and 24-48 hrs respectively in comparison to ondensetron group in which $50 \%, 63.34 \%, 90 \%$ and $93.3 \%$.

Conclusion: Prophylactic therapy with palonosetron is more effective than ondensetron for prevention of postoperative nausea and vomiting after laparoscopic cholecystectomy.

Keywords: Palonosetron, Ondensetron, Postoperative Nausea and Vomiting (PONV), Laparoscopic surgery.
\end{abstract}

\section{Introduction}

Postoperative nausea and vomiting (PONV) is the most common distressing symptom occuring after surgery. Despite the advances in anaesthetic and surgical techniques, PONV is still persistent. Various factors contributing to PONV include patient characteristics, anaesthetic technique, type of surgery, and postoperative care. Patients undergoing laparoscopic surgeries are particularly at risk.

Postoperative emesis predispose the patients to aspiration of gastric contents, electrolyte imbalance, tension on suture line, venous hypertension, wound dehiscence, and it frequently delays discharge from post anaesthesia care unit (PACU) and is the leading cause of unexpected 
hospital admissions after planned ambulatory surgery.

Patients undergoing laparoscopic cholecystectomy are particularly at high risk for developing postoperative nausea and vomiting. Patient's overall incidence can be raised up to $80 \%$. $^{(1)}$

Non-pharmacologic methods have been studied for their efficacy in PONV prevention. These include acupuncture, electroacupuncture, transcutaneous electrical nerve stimulation, acupoint stimulation, and acupressure. These methods have not been shown to have consistent antiemetic property ${ }^{(2,3)}$.

Traditional antiemetic drugs used for PONV include anticholinergics (e.g. scopolamine) phenothiazines (e.g.prochlorperazine) antihistamines (e.g.promethazine), butyrophenones (e.g.droperidol), and benzamide (e.g. metoclopramide).

Promethazine and prochlorperazine belong to a group of drugs known as phenothiazines, which act primarily via a central antidopaminergic mechanism in the chemotactic zone but it is associated with drowsiness ${ }^{(4)}$.

Metoclopramide is an antiemetic used widely in clinical practice. It is an effective antiemetic when administered at dose of $0.2 \mathrm{mg} / \mathrm{kg}$ but higher doses (>0.2 $\mathrm{mg} / \mathrm{kg}$ ) of metoclopramide are associated with extrapyramidal reactions, such as akathisia and motor restlessness ${ }^{(5,6)}$.

Dexamethasone is an inexpensive and effective antiemetic drug, with minimal adverse effects after a single-dose administration. The exact mechanism of antiemetic action of dexamethasone is not fully understood ${ }^{(7)}$.

5-hydroxytryptamine subtype 3 (5HT-3) receptor antagonist produce pure antagonism of the 5-HT3 receptor. The introduction of this class of drugs in the 90s represents a major improvement in the pharmacotherapy of chemotherapy and radiation therapy-induced nausea and vomiting. They have since proven to be highly effective in the prevention and treatment of postoperative nausea and vomiting. They are not effective in the treatment of motion induced nausea and vomiting.
Their actions involve both central and peripheral mechanism $^{(8)}$.

Ondansetron, the first 5-HT3 receptor antagonist to be introduced, is the most commonly used drug of this class. Other includes granisetron, tropisetron, dolosetron, palonosetron and ramosetron. Several other studies ${ }^{(9)}$ have shown ondansetron to be superior antiemetic than dexamethasone.

Palonosetron is a second generation 5HT3 receptor antagonist and having long elimination half life. Several studies ${ }^{(10)}$ have concluded that palonosetron is a better antiemetic than ondansetron in prevention of PONV.

When used in combination with Ondansetron and Palonosetron, Dexamethasone ${ }^{(11,12)}$ was reported to be effective in reducing PONV. There is no evidence that any dose of a single antiemetic can achieve more than $60-70 \%$ prevention of nausea and vomiting.

Our study sought to compare the effectiveness of 0.075mg Palonosetron plus 8mg Dexamethasone with that of $4 \mathrm{mg}$ Ondansetron plus $8 \mathrm{mg}$ Dexamethasone for PONV in patients undergoing laparoscopic surgery. We also studied the incidence of early or delayed vomiting, and the requirement of rescue antiemetics, and any side effects.

\section{Materials and Method}

Sixty patients age between 18 to 60 years belonging to American Society of Anaesthesia grade 1 and 2 randomly divided into 2 groups, each consist of 30 patients.

Group A: Palanosetron $0.075 \mathrm{mg}$ and Dexamethasone $8 \mathrm{mg}$

Group B: Ondansetron 4mg and Dexamethasone $8 \mathrm{mg}$

On day of surgery Anaesthesia machine, circuit, resuscitation equipments were kept ready. After confirmation of Nil Per Oral status patient was shifted to the operating room and connected to multi parameter monitor. Systolic blood pressure (SBP), Diastolic blood pressure (DBP), Meanarterial pressure(MAP), Pulse rate and 
saturation of Oxygen (SpO2) were recorded. Patient was premedicated with glycopyrrolate $0.2 \mathrm{mg}$ intravenous (iv) injection and fentanyl $2 \mu \mathrm{g} / \mathrm{kg}$ injection. Group A received intravenous injection of $4 \mathrm{mg}$ ondansetron and $8 \mathrm{mg}$ Dexamethasone and group B received intravenous injection of $0.075 \mathrm{mg}$ Palanosetron along with $8 \mathrm{mg}$ Dexamethasone before induction. All patient were preoxygenated for three minutes and induced with propofol (1\%) $1.5-2 \mathrm{mg} / \mathrm{kg}$ and succinylcholine $1.5-2 \mathrm{mg} / \mathrm{kg}$ to facilitate laryngoscopy and intubation. Oxygenation was continued by positive pressure mask ventilation using the Bains circuit. At the onset of apnea, using a laryngoscope with a Macintosh blade, intubation was performed with well lubricated, appropriate size cuffed oral endotracheal tube. After confirmation of the tube position, the cuff was inflated, and the tube was fixed.

Anaesthesia was maintained with oxygen $\left(\mathrm{O}_{2}\right)$, halothane and vecuronium $0.1 \mathrm{mg} / \mathrm{kg}$. Ventilation was controlled and adjusted to maintain the end tidal partial pressure of $\mathrm{CO}_{2}$ between 4.7 and 5.3 $\mathrm{kPa}(35-40 \mathrm{mmHg})$.

Laparoscopic surgery was performed under video guidance and involved four punctures of the abdomen. During surgery, patient was placed in the reverse trendelenburg position with the right side of the bed elevated and abdomen insufflated with $\mathrm{CO}_{2}$ through a veress needle to a pressure maximum of $12-14 \mathrm{mmHg}$. At cessation of surgery, residual neuromuscular block was reversed using intravenous Glycopyrrolate $0.005 \mathrm{mg} / \mathrm{kg}$ and Neostigmine $0.05 \mathrm{mg} / \mathrm{kg}$. After regaining muscle power to maintain spontaneous respiration and adequate tidal volume, patient was extubated. After extubation patient was oxygenated for 5 minutes. After discontinuation of oxygen via mask, patient was observed for oxygen saturation if it remains above $97 \%$, patient was shifted to recovery room and/or postoperative ward.

The duty doctor was asked to administer intravenous inj.metoclopromide $10 \mathrm{mg}$ as rescue antiemetic on every episode of vomiting in the 24 hours study duration and to document it.

Blood pressure, Heart rate, Respiratory rate was monitored and incidence of nausea, retching, and vomiting was recorded at 1hr, $4 \mathrm{hrs}, 12 \mathrm{hrs}, 24 \mathrm{hrs}$ and $48 \mathrm{hrs}$ postoperatively

The data was then collected and analysed. Statistics: Dependence of one qualitative character on groups was tested using chi square test. The analysis was performed using IBM SPSS version 2016, $p<0.05$ was considered as statistically significant.

\section{Observations \& Results}

In total, 60 patients were recruited, all of them completed the study. Baseline demographic profile and clinical characteristics were comparable between both the groups with no statistically significant difference between them (p-value>0.05).

Table 1 Baseline demographic profile and clinical characteristics

\begin{tabular}{|l|c|c|c|}
\hline & $\begin{array}{c}\text { ONDANSETRON } \\
\text { GROUP }\end{array}$ & $\begin{array}{c}\text { PALONOSETRON } \\
\text { GROUP }\end{array}$ & $\begin{array}{c}\text { p- } \\
\text { VALUE }\end{array}$ \\
\hline Male/Female & $2 / 28$ & $1 / 29$ & 0.55 \\
\hline AGE in years & 39.86 & 43.22 & 0.0786 \\
(mean \pm SD) & \pm 9.353 & \pm 8.541 & \\
\hline WEIGHT in kg & 54.62 & 55.46 & 0.5168 \\
(mean \pm SD) & \pm 6.779 & \pm 5.383 & \\
\hline HEART RATE per min & 81.28 & 81.31 & 0.7325 \\
(mean \pm SD) & \pm 8.676 & \pm 8.782 & \\
\hline ARTERIAL PRESSURE & 122.67 & 124.56 & 0.5438 \\
in mmhg (sys \pm SD) & \pm 6.997 & \pm 6.240 & \\
\hline ARTERIAL PRESSURE & $81.43 \pm 5.37$ & $80.73 \pm 5.54$ & 0.585 \\
in mmhg (dys \pm SD) & & & \\
\hline
\end{tabular}

The incidence of nausea was significantly lower in the palonosetron group than in the ondansetron group during the first $12 \mathrm{~h}(\mathrm{p}<0.05$, Table2). But as a long term (12-48 hrs) effect incidence of postoperative nausea and vomiting is less in Palonosetron Group but not statistically significant $(\mathrm{p}>0.05)$ 
Table 2 Comparison of frequency of PONV in positive period

\begin{tabular}{|l|c|c|c|c|}
\hline $\begin{array}{l}\text { Post- } \\
\text { operative } \\
\text { period }\end{array}$ & & $\begin{array}{c}\text { ONDANSETRON } \\
(\mathrm{n}=30)\end{array}$ & $\begin{array}{c}\text { PALONOSETRO } \\
\mathrm{N}(\mathrm{n}=30)\end{array}$ & $\mathrm{p}$ - VALUE \\
\hline \multirow{3}{*}{$0-4$ hours } & NAUSEA & $15(50 \%)$ & $4(13.33 \%)$ & 0.005 \\
\cline { 2 - 5 } & VOMITING & $8(26.66 \%)$ & $2(10 \%)$ & 0.079 \\
\hline \multirow{2}{*}{$4-12$ hours } & NAUSEA & $11(36.66 \%)$ & $4(13.33 \%)$ & 0.073 \\
\cline { 2 - 5 } & VOMITING & $4(13.33 \%)$ & $2(6.66 \%)$ & 0.667 \\
\hline \multirow{2}{*}{$12-24$ hours } & NAUSEA & $3(10 \%)$ & $2(6.66 \%)$ & 0.640 \\
\cline { 2 - 5 } & VOMITING & $2(6.66 \%)$ & $1(3.33 \%)$ & 0.553 \\
\hline $24-48$ hours & NAUSEA & $3(10 \%)$ & $2(6.66 \%)$ & 0.640 \\
\cline { 2 - 5 } & VOMITING & $1(3.33 \%)$ & $0(0 \%)$ & 0.0079 \\
\hline
\end{tabular}

Complete response (no PONV and no rescue antiemetic) was more in the palonosetron group compared with the ondansetron group and the need for rescue antiemetics was less during 0 - 48 $\mathrm{h}$ time interval ( $\mathrm{p}>0.05)$ (Table3). Incidence of adverse effects (Fig. 3) were comparable between the two groups.

Table 3 Incidence of Complete Response and need for Rescue Anti-emetic

\begin{tabular}{|l|c|c|c|}
\hline & $\begin{array}{c}\text { ONDANSETRON } \\
(\mathrm{n}=30)\end{array}$ & $\begin{array}{c}\text { PALONOSETRON } \\
(\mathrm{n}=30)\end{array}$ & $\begin{array}{c}\mathrm{p}- \\
\text { VALUE }\end{array}$ \\
\hline $\begin{array}{l}\text { COMPLETE } \\
\text { RESPONSE }\end{array}$ & $22(74.11 \%)$ & $27(89.44 \%)$ & 0.182 \\
\hline $\begin{array}{l}\text { RESCUE } \\
\text { ANTIEMETI } \\
\text { CS }\end{array}$ & $14(46.66 \%)$ & $9(30 \%)$ & 0.288 \\
\hline
\end{tabular}

Fig 1 Incidence of Nausea in Different Groups Within Thke Defined Time Perio

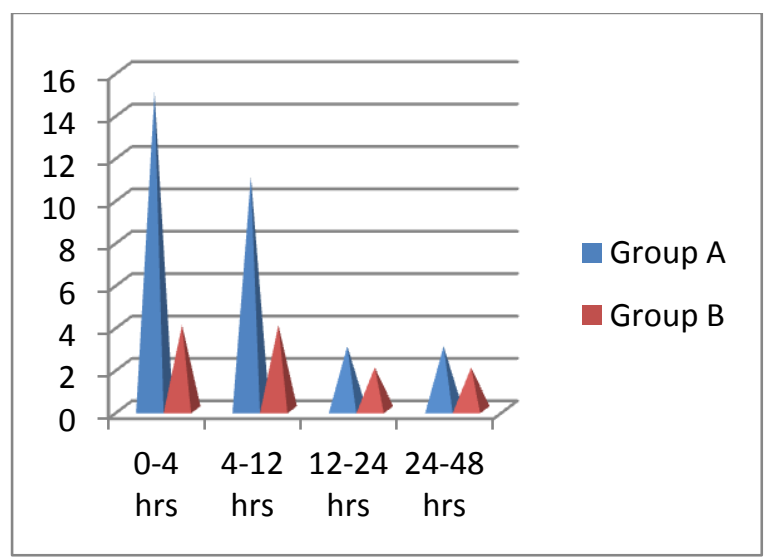

Fig 2 Incidence of Emesis in Different Groups Within the Defined Time Period

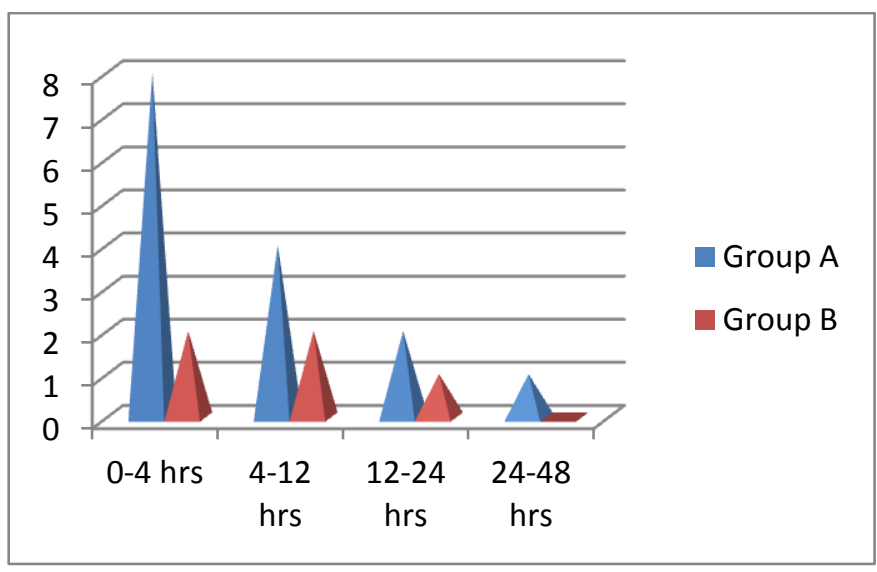

Fig 3 Comparison of the Incidence of Side Effects of in Different Groups

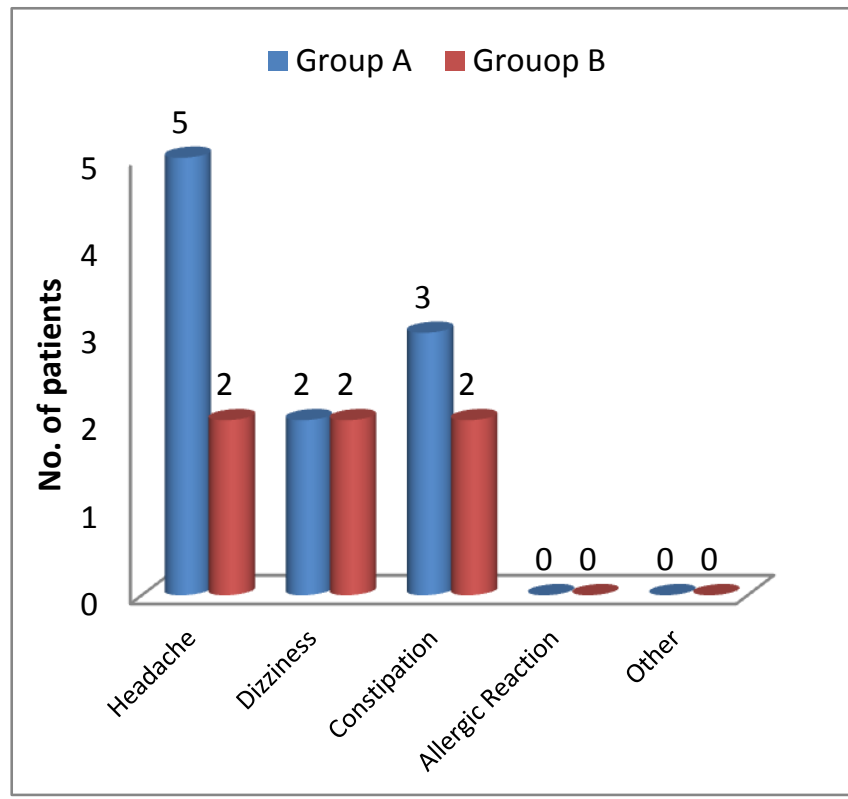

\section{Discussion}

A significant proportion of patients experience PONV despite the widespread use of prophylactic antiemetics, including 5-HT3 receptor antagonists. ${ }^{13}$ 5HT3 receptor antagonist have an enviable safety profile, with minor sideeffects and rare cardiac conduction abnormalities. Ondansetron was the first 5-HT3 receptor antagonist to be marketed and has frequently been used to controlPONV. ${ }^{14}$ Palonosetron a second generation 5-HT3 antagonist has unique structural, pharmacological and clinical properties that distinguish it from other 5-HT3 antagonists. ${ }^{15}$ It is the most 
recently introduced member of this class of drugs in India. It has a greater binding affinity and longer half-life (40hrs) than older 5-HT3 antagonists. The present study was carried out mainly to see the see the comparative efficacy of the new and much promising long-acting 5-HT3 antagonist palonosetron against ondansetron in prevention of PONV in patients undergoing laparoscopic cholecystectomy.

In our study, the dose selection for palonosetron was based on the studies of Candiotti et al. ${ }^{16}$, the minimum effective dose of palonosetron in the prophylaxis of PONV is $0.075 \mathrm{mg}$, and this has been approved by the food drug agency (FDA). US Food and Drug Administration (FDA) also approved a single dose of palonosetron $0.075 \mathrm{mg}$ for preventing PONV for up to first 24 hours after the surgery. ${ }^{8,17}$

The incidence of PONV is associated with many factors like age and gender (female gender, younger age increase the risk of PONV),history of motion sickness or PONV, smoking status (smoking decreases the risk of PONV), postoperative opioid use, type and duration of surgery, anaesthesia and ambulation. ${ }^{18,19}$ These factors were comparable between both groups in the present study.

In the present study, palonosteron $0.075 \mathrm{mg}$ was more effective at reducing PONV than ondansetron 4mg. This could reflect the high receptor affinity of palonosetron for 5-HT3, with a low affinity demonstrated for other receptors and the longer duration of action. ${ }^{20}$

\section{Conclusion}

The current study concludes that efficacy of ondansetron $4 \mathrm{mg}$ plus dexamethasone $8 \mathrm{mg}$ and palonosetron $0.075 \mathrm{mg}$ plus Dexamethasone $8 \mathrm{mg}$ in post-operative nausea and vomiting was almost comparable. Since both drugs are serotonin antagonists with almost similar pharmacokinetic and dynamic behaviour profile was also similar in both treatment groups.. The overall patient satisfaction and adverse effect profile were comparable between both the groups.

\section{References}

1. Paech Muchatuta NA and MJ: Management of post operative nausea vomiting:focus on Palanosetron; Ther Clin Risk Manag. 2009 feb; 5 (1): 21-34

2. Dundee JW, Chestnutt, Ghaly RG,Lyans AG.Traditioal Chinese acupuncture : a potentially useful antiemetic?Br Med J (clin Res Ed) 1986;293:583-584.

3. LeeA,Fan LT. Stimulation of the wrist acupuncture point p6 for preventing postoperative nausea and vomiting. Cochare Database Syst Rev.2009;(2): CD003281.

4. Khalil S, Philbrook L, Rabb M, et al. Ondansetron and Promethazine combination or promethazine alone reduces nausea and vomiting after middle ear surgery: J Clin Anesth, 1999; 11: 596600.

5. Fujii $\mathrm{Y}$, Toyooka $\mathrm{H}$, Tanaka $\mathrm{H}$ : Prophylactic anti-emetic therapy with Granisetron, Droperidol and Metoclopramide in female patients undergoing middle ear surgery: Anaesthesia, 1998; 53: 1165-8.

6. Fujii $\mathrm{Y}$, Tanaka $\mathrm{H}$, Kobayashi N: Prevention of postoperative nausea and vomiting with antiemetics in patients undergoing middle ear surgery: comparison of a small dose of Propofol with Droperidol or Metoclopramide:Arch Otolaryngol Head Neck Surg, 2001; 127:25-8.

7. Henzi I, Walder B, Tramer MR: Dexamethasone for the prevention of postoperative nausea and vomiting: a quantitative systematic review: Anesth Analg, 2000; 99: 186-94.

8. Bunce KT, Tyers MB: The role of 5-HT3 in postoperative nausea and vomiting: $\mathrm{Br} \mathrm{J}$ Anaesth, 1992; 69: 60S-62S.

9. EIDI M khaosro kolahdouzan Hamesh Hosseinzadeh and Tabaqi R. Compared of preoperative Ondensetron 
and Dexamethasone in the prevention of Post- tympanoplasty Nausea and vomiting.Iran J Med sci September 2012; Vol37 No 3.

10. Berrin Isik,Nedim Cekmen,Mustafa Arslan, Ozgur Ozsoylar, Aysegul Z.Kordan,Mehmet Akcabay compared the antiemetic effect of Ondensetron and Dexamethasone on middle ear surgery. Saudi Med J 2006; Vol. 27(5):646-651

11. SK Park and EJ CHO compared Palonosetron with Ondensetron in preventing postoperative nausea and vomiting after gynaecological laproscopic surgery the Journal ofminternational medical research 2011;39:399-407

12. Chakravarty N. and Raghuvanshi S.K. studied efficacy of Palonosetron and Ondensetron in post operative nausea vomiting in middle ear surgery.Int $\mathrm{J}$ Bio Sci 2013oct;4(4) (B) 67-74.

13. Ho KY, Gan TJ. Pharmacology, pharmacogenetics, and clinical efficacy of 5-hydroxytryptamine type 3 receptor antagonists for postoperative nausea and vomiting.CurrOpinAnaesthesiol

2006;19:606-11.

14. Muchatuta NA, Paech MJ. Management of postoperative nausea and vomiting: focus on palonosetron. TherClin Risk Manage 2009;5:21-34.

15. Candiotti KA, Kovac AL, Melson TI, Clerici G, JooGan T. A randomized, double-blind study to evaluate the efficacy and safety of three different doses of palonosetron versus placebo for preventing postoperative nausea and vomiting.AnesthAnalg 2008;107:445-51.

16. Kovac AL: Prevention and treatment of postoperative nausea and vomiting. Drugs 2000; 59: 213 - 243.

17. Tramer MR, Reynolds DJ, Moore RA, McQuay HJ. Efficacy, dose-response, and safety of ondansetron in prevention of postoperative nausea and vomiting: a quantitative systematic review of randomized placebo controlled trials. Anesthesiology1997; 87: 1277 -1289.

18. Andrews PLR, Hawthorn J. The neurophysiology of vomiting.Clinical Gastroenterology 1988; 2: 141-168.

19. Vance JP, Neill RS, Norris W. The incidence and aetiology of postoperative nausea and vomiting in a plastic surgical unit; British Jour.Of Plastic Surgery 1973; 26:336-339.

20. Stein JM. Factors affecting nausea and vomiting in a plastic surgery patient. Plast Reconstruct Surg 1982; 70:505-11. 